\title{
Towards a decolonial hermeneutic of experience in African Pentecostal Christianity: A South African perspective
}

\begin{tabular}{|c|c|}
\hline \multicolumn{2}{|c|}{$\begin{array}{l}\text { Authors: } \\
\text { Mookgo S. Kgatle }{ }^{1} \text { (1) } \\
\text { Thabang R. Mofokeng }\end{array}$} \\
\hline \multicolumn{2}{|c|}{$\begin{array}{l}\text { Affiliations: } \\
{ }^{1} \text { Department of Christian } \\
\text { Spirituality, Church History } \\
\text { and Missiology, University } \\
\text { of South Africa, Pretoria, } \\
\text { South Africa }\end{array}$} \\
\hline \multicolumn{2}{|c|}{$\begin{array}{l}{ }^{2} \text { Christian Ministry and } \\
\text { Leadership, Faculty of } \\
\text { Theology, North-West } \\
\text { University, Potchefstroom, } \\
\text { South Africa }\end{array}$} \\
\hline \multicolumn{2}{|c|}{$\begin{array}{l}\text { Corresponding author: } \\
\text { Mookgo Kgatle, } \\
\text { kgatles@yahoo.com }\end{array}$} \\
\hline \multicolumn{2}{|c|}{$\begin{array}{l}\text { Received: } 22 \text { May } 2019 \\
\text { Accepted: } 02 \text { July } 2019 \\
\text { Published: } 30 \text { Oct. } 2019\end{array}$} \\
\hline \multicolumn{2}{|c|}{$\begin{array}{l}\text { How to cite this article: } \\
\text { Kgatle, M.S. \& Mofokeng, T.R., } \\
\text { 2019, 'Towards a decolonial } \\
\text { hermeneutic of experience } \\
\text { in African Pentecostal } \\
\text { Christianity: A South African } \\
\text { perspective', HTS Teologiese } \\
\text { Studies/Theological Studies } \\
\text { 75(4), a5473. https://doi.org/ } \\
\text { 10.4102/hts.v75i4.5473 }\end{array}$} \\
\hline \multicolumn{2}{|c|}{$\begin{array}{l}\text { Copyright: } \\
\text { (c) 2019. The Authors. } \\
\text { Licensee: AOSIS. This } \\
\text { is licensed under the } \\
\text { Creative Commons } \\
\text { Attribution License. }\end{array}$} \\
\hline \multicolumn{2}{|l|}{ Read online: } \\
\hline 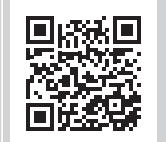 & $\begin{array}{l}\text { Scan this QR } \\
\text { code with your } \\
\text { smart phone or } \\
\text { mobile device } \\
\text { to read online. }\end{array}$ \\
\hline
\end{tabular}

The idea for this article was developed in ecumenical discussion regarding the worrisome developments in some neo-Pentecostal ministries where stories of snake-eating, petroldrinking, false prophecies and so on were being alleged. A burning question during the discussion was: what is it with the hermeneutic of experience that makes it possible for such stories to arise? Furthermore, how can this situation be remedied? The researchers set to answer this question by conducting a literature study on the subject of hermeneutics of African Indigenous Churches (AICs), neo-Pentecostalism and Mission Pentecostalism. The inclusion of AICs and Mission Pentecostalism follows the scholarly consensus led by Allan Anderson in which all three together constitute African Pentecostalism. This article offers a critical reflection on the corrosive role of fundamentalist-inspired exclusivism, judgementalism and pride, which feed ignorance of the basic oneness of African Pentecostal Christianity. It concludes that abuse abounds in the divisions and maintenance of the above-mentioned fundamentalist attitudes and raises the necessity of creating awareness of belonging to one community. This community's historical experience of the activity of the Spirit and Scripture may serve as critical input into its hermeneutic, hopefully lessening if not eradicating abuse.

Keywords: Pentecostal hermeneutic; African Pentecostal Christianity; Holy Spirit; Pentecostal experience; Decolonisation.

\section{Introduction}

This article is located within the current challenges in African Pentecostal Christianity (APC) like the abuse of Scriptures, prophecy and contradictions in experienced and revealed truth as inspired by the Holy Spirit.

The actions and explanations of Pastors Lesego Daniel and Lethebo Rabalago of Rabboni Centre Ministries and Mount Zion General Assembly, respectively, illustrate the challenges facing APC. Both these ministers attribute feeding their respective followers grass and spraying them with an insecticide to the instruction of the Holy Spirit. Rabalago further states that 'He uses anything that the Lord directs him to use to heal people' (see Kgatle 2017:4). Writing about the actions of the likes of Daniel and Rabalago, Resane (2016:3) fingers 'the egoism central to the hermeneutics of the charismatic Christianity in South Africa'. By 'charismatic Christianity', Resane (2017) refers to the movement born from the revivals of the 1970s. The pentecostalisation of mainline churches in some instances resulted in the establishment of independent congregations often founded by theologically untrained leaders, although some did some training with American-based or related Bible Schools. With neo-Pentecostalism came theological aberrations like the notorious 'prosperity gospel'. The proponents and adherents of this gospel believe in 'big and better now' and the willingness to plough all one has to secure such a desired end.

Although the challenges that inspired the writing of this article emanate from the neo-Pentecostal sector, the researchers locate this sector under the umbrella of APC. Doing so locates this research theoretically under Anderson's (2005:67) perspective that recognises the centrality of the experience of the Holy Spirit in pneumatic African Indigenous Churches (AICs), Mission Pentecostalism and neo-Pentecostalism. The researchers take cognisance of sectional application of the term 'African Pentecostal/ism' by various scholars. For example, Phiri (2009) limits it to the movement resulting from the 1970s revival, while Clark (2001:89) applies it to Africans in formerly white-led Mission Pentecostal denominations only. Maxwell's (2006) application of the term 
brings neo-Pentecostals and Mission Pentecostals together while excluding followers of pneumatic AICs. Adopting the Andersonian perspective places neo-Pentecostal abuses in a broader context of the African Christian community of the Spirit and potentially avails theoretical resources to handle these abuses. Considering the diversity of attitudes and experiences resident in the African Christian community of the Spirit, and the central role experience plays in Pentecostal hermeneutics, this article is an attempt to re-imagine the hermeneutic of experience in APC as a decolonial discourse.

Noting that at the centre of the challenges APC is undergoing lie the desire and belief in supernatural intervention; that these desire and belief find life in the way Scripture is read in APC, the researchers ask: what is it with the hermeneutic of experience that enables stories of abuse to arise and how can this situation be remedied? The researchers argue that the failure to discern the African Christian community of the Spirit and factor in its diverse historic experiences into a unified hermeneutic of experience for the well-being of this entire community is at the root of talked about abuses. Attitudes like spiritual pride, exclusivism and judgementalism, all which the researchers will discuss in relation to the hermeneutic of experience, characterise the failure to discern the African Christian community of the Spirit. Working within the Andersonian framework, the researchers propose a discerning and decolonial hermeneutic that will be able to test every supposed activity of the Spirit against Scripture and the historical communal experience of APC. The method used for the study is a decolonial discourse in the sense that a Pentecostal hermeneutic of experience unlike previous studies is applied to an African context.

\section{A working definition of a Pentecostal hermeneutic of experience}

Any discussion on Pentecostal hermeneutic raises a question on the existence of an authentic Pentecostal hermeneutics. We need to view a Pentecostal hermeneutic as the hermeneutic in which the Holy Spirit is involved in the interpretation of the Scriptures. When the Holy Spirit is involved, according to Pentecostals, there shall be a proper interpretation. The reason for this is that Pentecostals are inclined to the work of the Holy Spirit in almost everything they do (Karkkainen 1998:87). Thus, the Holy Spirit is involved during interpretation in stimulating the Scriptures and working in the lives of the Pentecostal believers to an extent that they are able to become ministers of the gospel to other nations (Nel 2015:3). The hermeneutic of experience, according to Archer (2004:41), makes 'The Pentecostal community a distinct, coherent narrative tradition within Christianity. Pentecostal communities are bound together by their charismatic experiences and common story'. Pentecostals believe that the Holy Spirit, who did great works in the life of Christ like his resurrection and other powerful works by the Apostles in the book of Acts, lives in them. The same Holy Spirit is able to give them revelations today (Yong 2007:247). Pentecostals believe that the Holy Spirit is able to draw to their attention relevant Scriptural passages that will help them deal with contextual challenges in their lives. Hence, many Pentecostal preachers do not even see a need to go through theological training because the Holy Spirit is the revelatory agent between the Bible and its reader (Becker 2004:32). Plüss (2003:17) asserts, 'By attributing an important role to the Holy Spirit and holiness, Pentecostals acknowledge that any religious experience is but a process in their Christian living'.

A Pentecostal hermeneutic does not necessarily dismiss a scientific inquisition of Scriptures, but rather places the role and work of the Holy Spirit above the zeal for a scientific knowledge. Thus, scientific inquisition only becomes an introduction to a revelation that is already inspired by the Holy Spirit (Nel \& Van Rensburg 2016:4). This is possible because the Holy Spirit plays an important role in the fellowship of believers, their prayer meetings and understanding of the Bible, leading to the deepening of spiritual life (Gräbe 2005:126). Furthermore, Pentecostals acknowledge that the revelation of God has moved from God the Father to God the Son and the Holy Spirit. Therefore, being in a relationship with the Holy Spirit makes a believer to access the revelation of Christ written in the Bible. Consequently, the believer is able to know the mind of God through the same Holy Spirit (Wenk 2003:64). In essence, the Holy Spirit bridges the gap that exists between the biblical time and the real reader of the Bible today. This is possible because the Holy Spirit is a neutral agent that knows the time of the author and the time of the reader and is therefore able to merge the two. Thus, a contextual reading of Scriptures for Pentecostals becomes possible because of the work of the Holy Spirit who is able to provide meaning to the modern reader of Scriptures in the 21st century.

In summary, Pentecostal hermeneutic of experience recognises the Bible as we have it today as the word of God and that one is able to read and understand it only through the work of the Holy Spirit. This is not to ignore scientific knowledge but placing the work of the Holy Spirit above scientific knowledge. Therefore, fellowship with God through Scripture reading, prayer, worship and other activities is pivotal in Pentecostalism as they enhance the knowledge about God found in the Bible. Furthermore, this demands for every believer to have a personal relationship with God and be able to read and interpret the Bible to preach it to others who do not have the same privilege or access to God. The essence of these practices among Pentecostal believers is to be able to engage with the Bible as the church through the work of the Holy Spirit (Moore 1987:4). While a Pentecostal hermeneutic as the work of the Holy Spirit makes it distinct from other hermeneutics, the danger is when Scriptures are quoted or used out of context in order for a pastor or prophet to drive his or her own agenda. The danger is when the word spoken by a prophet is taken as the final word on one hand but abusing the listeners or believers on the other. The main problem, as pointed out by Plüss (2003:3-4), is that 'an average Pentecostal cares little about hermeneutics, he or she would be quick to agree that it is by the presence and power of the Holy Spirit that a particular religious experience is caused and makes sense'. 


\section{The sub-traditions of African Pentecostal Christianity}

From an Andersonian perspective, APC has three subtraditions, namely, denominationally based Pentecostal communities associated with western Pentecostalism, African indigenous Pentecostals who, in Southern Africa, broke away from white-led denominational Pentecostalism and lastly, the neo-Pentecostal movement born of the 1970s and 1980s revivals. Each sub-tradition embodies diverse experiences, attitudes and approaches towards race, culture, church polity, mission and so on. For example, Mission Pentecostalism is bureaucratic, averse to African traditional culture, western inclined both in its culture and biblical hermeneutics and evangelistic. African indigenous Pentecostalism is monarchical, attuned to African traditional culture, orientated towards the Old Testament and a healing movement. Neo-Pentecostalism leans towards personality cultism as the founder dominates everything and everybody in the church he or she founded (Khanyile 2016:22,27; Resane 2017:5), often based in one locale. However, recently, some ministries have begun to grow branches in other locales in the country of origin and internationally. It is a youthful movement, culturally cosmopolitan and business as well as media savvy.

Of the three sub-traditions, the indigenous Pentecostals of the AIC movement have been the most misunderstood and rejected by other Pentecostal sub-traditions, the greater Christian community and the academy. Anderson (2005:69) locates the negative attitude these Pentecostals received in the missionary establishment for it seemed necessary to demonise them to prevent mission converts from joining the AICs. The publication of Bengt Sundkler's Bantu Prophets (1961) not only gave the academy a peek into pneumatic AICs but also influenced it negatively to see indigenous Pentecostalism as a 'bridge back to heathenism' (Sundkler 1961:55). He did soften his stance later. Bond (1974:14) outrightly labelled them 'a tribal religion masquerading as Christianity'. Despite this negativity, a positive evaluation developed from within the academy, starting with Hollenweger (1972:151) who was the first to apply the label 'African Pentecostals' to pneumatic AIC believers. Anderson (2005:69) argues for their inclusion under the Pentecostal label on the basis of a common ascription to the Holy Spirit of phenomena associated with ministry in these churches, and among the Pentecostals. Several scholars have followed this path. A comparative study by Gunda and Vengeyi (2018:59) regarding pneumatic AICs and Pentecostals in Zimbabwe supports Anderson's proposal of considering these churches to be Pentecostal. However, Larbi (2002:146) continues to advocate against their inclusion under Pentecostalism because of their continuity with the African religio-cultural world that he argues makes them incompatible with Pentecostalism. The academy recognises the leadership of AICs in indigenising the gospel.

The other two sub-traditions, the one traditionally referred to as 'Pentecostal/ism', and neo-Pentecostalism, are in rapport with one another. Anderson (2005:69) submits that they recognise each other's credentials as 'born again' and fellow participants in the Holy Spirit. Anderson (2002), Mathole (2005) and Maxwell (2006) recognise the contribution of several denominational Pentecostal evangelists such as Nicholas Bhengu of the Assemblies of God and Richard Ngidi as well as Reinhard Bonnke, both from the Apostolic Faith Mission (AFM), in sparking the neo-Pentecostal revival in the 1970s and 1980s in Southern Africa.

African-independent neo-Pentecostal ministries emerged from this revival. It is this sector that is plagued by allegations of abuse that prompted an investigation by the Council for the Protection and Promotion of the Rights of Cultural, Linguistic and Religious Communities (CLR) (Kgatle 2017; Khanyile 2016; Resane 2017).

The operational space of neo-Pentecostalism may have a greater contribution to abuse. Firstly, independence from denominational or any structures of support and accountability as well as the entrepreneurial investment of self and sometimes personal resources by the founding pastor, bishop, apostle or prophet intensify the need for innovativeness to not only survive but thrive in a highly competitive environment. That the neo-Pentecostal sector is the most business-like in organisation, promotion of personalities, programmes and supposedly sacred objects on offer is a testimony to competition in the sector and also to orientation to capitalist market economy. Secondly, the aura of the founding pastor, bishop, apostle or prophet as the mouthpiece of God whose word carries such finality that there is no recourse against it; thirdly, the prerogative this person exercises to originate and pronounce new insights as prophecy or revelation, which in some instances become doctrine; and fourthly, the rate at which these ministries form, proliferates diverse practices with attendant theological emphases (Khanyile 2016:15). All these, and the lack or rejection of theological training, have generated a great concern in both mainline and Pentecostal denominations, the broader public and the government.

\section{A critical reflection on a hermeneutic of experience in African Pentecostal Christianity}

The aim in this section is to critically reflect on the hermeneutic of experience all the sub-traditions of APC subscribe to, in the light of corrosive attitudes of spiritual pride, exclusivism and judgementalism as well as ignorance of fundamental oneness of the APC.

\section{The hermeneutic of experience and spiritual pride}

The question of spiritual pride in APC is not one written about that much. By spiritual pride is meant a sense of aloofness because of one having certain spiritual experiences, including the charismata. An environment that may easily lend itself to manifestations of this condition is one where 
there are believers deemed to be without the charismata or any mystical experiences associated with the Spirit by those who claim these experiences. Mathole (2005:180) writes about the experience of pride related to charismatic phenomena in the mainline churches in South Africa in the 1970s. He links the formation of independent neo-Pentecostal churches to the pressure mainline leaders exerted on charismatics within these denominations because of the latter's perceived elitism. Akoko (2007:147-148, 151) portrays a similar situation of perceived pride, exertion of pressure and eventual formation of independent ministries in the Cameroonian Presbyterian church and so does Phiri (2009) about the Reformed Church in Zambia. In the mainline churches, the 'born again' experience and spiritual baptism with related charismata became sources of pride and eventual conflict. For a Pentecostal denomination such as the AFM, testimonies of being born again made in every worship service resulted in animosity and eventual joining of mostly Zionist-Apostolic churches by those who felt denigrated to a non-Christian status. There is anecdotal evidence that some believers, who have not participated in glossolalic experience within some Pentecostal environments, feel their status as Christians belittled by those who have such experiences.

Kgatle (2017) writes about the recent situation in the South African neo-Pentecostal circles where followers have been fed snakes, grass and poisonous leaves; made to drink Dettol (an antiseptic) and petrol; and sprayed with doom (an insecticide). Citing Resane (2016), he points at the elitist pretensions of pastors he considers fake. These pastors consider themselves freed from natural, moral and other strictures, therefore do not value theological and ministry preparation. They grave and cultivate celebrity status from which they also benefit. Therefore the propensity for risky behaviour and practices is high.

Despite the outcry made against the abovementioned practices, the attitude of some of the followers tends toward feelings of untouchability. In the comments section of the Facebook page of Rabboni Ministries, one of the sites where Kgatle's 'bizarre practices' took place, some followers criticise those who call out these practices as lacking spirituality, being under the 'anointing of confusion' and jealous because of lack of power. For these followers, they are participants in the promise Jesus made to his disciples that they 'shall do greater works' (Jn 14:12). With the followers demonstrating this untouchable attitude, they prop up their leaders who appear only too glad to receive unwavering support in a world they perceive as being antagonistic. In this way, the hermeneutic of experience in APC risks spiritual pride for several reasons. Firstly, because it divides Christians into the haves and the have nots and in doing so it fosters elitism. Secondly, because elitism discredits the scriptural vision of egalitarian community where the material and/or spiritual poverty of the poor is not a reason for their ill treatment and marginalisation - all, who are by grace God's children and members of his church, are equal participants who are also variously gifted by the same grace. However, these reasons are not peculiar to APC. They apply to the whole Pentecostal tradition too.

\section{The hermeneutic of experience and exclusivism}

Several scholars have noted the corrosive influence of American fundamentalist hermeneutic on the African Pentecostal movement, especially the Mission and neo-Pentecostal sub-traditions. Van Dijk (2000:11) sees the Mission Pentecostal movement as being fundamentalist not only in theology, but in the construction of its identity and relations vis-à-vis pneumatic AICs, mainline Christianity and traditional culture. Dube (2014:2), Gabaitse (2015) and Nel (2017) highlight gender exclusion among Pentecostals which they ascribe to a specific anti-Pentecostal hermeneutic in the movement. According to Dube (2014:2) and Nel (2017), insistence on biblical inerrancy, which Pentecostals have adopted from fundamentalism, explains the exclusion of women from leadership. Gabaitse $(2015: 5,10)$ formulates the problem as a specific adherence to biblical authority that demands obedience to 'literal readings of the Bible and proof texting'. From a gender perspective, the fundamentalist hermeneutic extant in APC upholds patriarchy. Thus, it subjects women to indignity and abuse. It is interesting that the victims of neo-Pentecostal abuse in several instances mentioned in the media were women.

Mofokeng and Madise (2019:2) in their account on 'evangelicalisation in the Apostolic Faith Mission' exemplify Van Dijk's (2000) point about the 'fundamentalist turn' in African Pentecostalism. This denomination that Clark (2001:81) submits to be 'the oldest and one of the largest Pentecostals denominations in South Africa' successfully destroyed Zionist-like identity among its African members a process that began in 1929 and was only beginning to bear fruit in the 1970s. Hwata (2005:110) writes about a shift from the Old Testament to the New Testament, from mainly rural traditionalist culture to mainly urban westernised one and from spirit-centredness to Christ-centredness in the AFM (of South Africa and Zimbabwe) in the 1970s. Interestingly, and according to Van Dijk (2000), the Africa of the 1970s was caught up in neo-Pentecostal revival that swept in the youth and the educated, resulting in independent neo-Pentecostal ministries. He refers to this revival as the 'fundamentalist turn' in African Pentecostalism and blames the European, American and South African evangelistic activity (Van Dijk 2000:7). Describing the impact of the revival, Van Dijk (2000:11) writes of 'social unrest and conflicts' as well as 'entire families upset as they [were being] driven apart'. The creation of exclusive identities was a violent affair that drew from fundamentalist confidence in literal hermeneutic.

However, an APC informed by the founding theological insight and early history of the worldwide movement is incompatible with exclusivism. Early Pentecostalism was born from the margins of society, where all sorts of oppressions were the norm. Pentecostalism provided an affirming space for the marginalised, helping them to overcome racism, sexism, ageism, classism and so on, for as long as primacy was given to the experience of the Spirit. Theologically, Dube (2014:2) argues that Pentecostalism owes its existence to its insight into the egalitarianism of the 'body 
of Christ' concept - that every part, therefore member, has a role ordained and energised by the Spirit. According to Gabaitse (2015), the continued activity of the Spirit in illuminating the biblical text towards life-giving and emancipatory hermeneutic is central to Pentecostal belief. Contextualisation of the gospel itself happened under the aegis of the Spirit.

\section{The hermeneutic of experience and judgementalism}

True to fundamentalist mentality, identity is grafted and protected by strict rules around beliefs, behaviour and relationships. Failure to observe these rules endangers the community to which they apply and to protect itself, censure and ultimately expulsion is meted against the offender who may be an individual or a group.

Considering that in the Andersonian sense APC is constituted by three strands or sub-traditions (Khorommbi 2001:16), judgementalism in association with the hermeneutic of experience cannot apply equally across this form of Christianity. Firstly, because pneumatic AICs, which constitute one strand, mostly consider themselves hospitals, and their concern is mainly healing (Anderson 2001:220). Consequently, they remain open to whoever seeks healing.

Secondly, because neo-Pentecostals have a relaxed approach to morality which Mathole (2005:189) attributes to their not being steeped into the holiness tradition of the older Pentecostals, and generally being young and educated. Furthermore, their main focus on being dispensers of the blessing of prosperity requires faith and offerings to be realised not morality per se (Ganiel 2010:132). In these quarters, material affluence among believers provides a shortcut to indications of who has God's favour. Old Pentecostalism, on the contrary, because of its association with fundamentalism, has been the most infected with judgementalism. Even there, Mathole (2005:189) argues that because of the similarity of the demographic of followers with neo-Pentecostalism after the rise of the latter, old Pentecostals lost their strictness such that the two became almost indistinguishable from one another. This indistinguishability, not only in moral attitude, but phenomenologically too, has led to scholars such as Ganiel (2010) adopting the nomenclature of 'Pentecostal-charismatic'.

\section{The hermeneutic of experience and ignorance of fundamental oneness of African Pentecostal Christianity}

Regardless of their social status and educational achievements, Africans seem to have a cultural predisposition towards experientialism. A Christianity such as the version introduced by missionaries, was therefore unable to satisfy this attribute of African personality (Clark 2001:83-84). Access to the Bible in African languages introduced Africans to possibilities of a Christian spirituality which missionaries did not want to realise for fear that it would mean revival of 'heathenism'. In this section, the intention is to discuss the
AICs, neo-Pentecostals and Mission Pentecostal churches against their common Africanness and highlight the necessity of mutual awareness and engagement as members of the same African Pentecostal community.

AICs, especially the pneumatic variant, led in contextualising Christianity to the African situation. Maxwell (2006:10-11) seems to view the idea of AICs as agents of contextualisation to mean uncritically reducing the gospel to a version of African religiosity; hence, he argues that these churches were not uncritical in their appropriation of the gospel and African culture. Indeed, AICs modified certain aspects of African culture even as they did to Christianity. The result was a Christianity that not only drew many people who were not Christian before, but it also received patronage from Africans in the mainline churches (Masenya 2005:36).

Anderson (1996:9) attributes the pulling power of AICs to the way they approach the Bible - in a manner that includes their Africanness - and credits them with answering African needs. These may be needs for community, spiritually vital religion with powerful functionaries, taboo-based ethical framework and so on. The similarity of the Old Testament and African religio-cultural world is what, according to Mojola (in press), inclined AICs to the former in an act that hermeneutically favours the context from which the Bible is understood (Anderson 1996:14). In this way, the Old Testament filters African culture, resulting in continuities and discontinuities that highlight the transformative power of the Bible in the creation of African Christianity (p. 23).

Regarding neo-Pentecostalism, scholars such as Gunda and Vengeyi (2018:57) are picking up signs that the movement may be coming closer to older pneumatic AICs in the role of the Old Testament and, by implication, African culture, is beginning to play in the leadership models and instruments of ministry. The emphasis on the anointing of the founderprophet, bishop or apostle suggests a gravitation towards Old Testament model of leadership that tends towards monarchism. ${ }^{1}$ The use of holy water or anointing oil and other tangibles among neo-Pentecostals is another indication of the growing similarity with pneumatic AICs (Omenyo 2014:138). This increasing similarity of neo-Pentecostals and pneumatic AICs seems to confirm Anderson's (2002:170) views about the two being versions of each other in different socio-economic and cultural locations. The persisting problem that even the South African state through its CRL Commission has picked up is one of commercialisation of the gospel through sale of holy water, anointing oil, church uniforms, appointments with clergy and so on (CRL Rights Commission 2017). Although CLR attempted to generalise, they cannot hide that most perceived abuses emanate from the neo-Pentecostal movement. Even some proposed solutions are better suited to the neo-Pentecostal movement than denominational churches (both Pentecostal and mainline) with long-established accountability structures

1.Almost all neo-Pentecostal ministries are still led by their founding leaders. It stands to be seen whether they would also opt for dynastic leadership like most pneumatic AICs at the death of these founders or not. 
and codes of conduct. The atomistic environment characteristic of neo-Pentecostalism is amenable to capitalist consumerist framework and entrepreneurial competitiveness that glamorise acquisition of bigger and better material goods for which those so sold on this theology are encouraged to aim for - unfortunately at huge financial cost to followers.

Mission Pentecostalism occupies a different space to AICs despite subscribing to the hermeneutic of experience. Mission Pentecostalism has long association with white Pentecostalism where it received tutelage (Clark 2001:87). Although Clark (2001:95) submits that Mission Pentecostals consider themselves African, they represent the success of missionary Christianity in the content of their beliefs and conduct of their lives. Missionaries had a problem with polygamy, initiation schools and ceremonies related to the ancestral cult - therefore, attendance at family gatherings to observe such (Burger Nel 2008:242). They proceeded to prohibit these practices with the consequence that many Mission Pentecostals are relationally estranged from their nonPentecostal kin. What remains are African surnames that others demand to know why these Pentecostals keep the surnames of families and ancestors they want nothing to do with. Mission Pentecostals carry a fragile identity formed and nurtured by a western hermeneutic that still remains in the hands of westerners. Its existence as a shadow of western Pentecostalism may be one of the reasons it is easy to ignore Mission Pentecostalism. In this situation, Mission Pentecostalism seems to not have a contribution to make towards a truly African Pentecostal Christianity and as such may even beg the question about its inclusion under the same canopy. According to Mofokeng (2018:117), a critical question facing Mission Pentecostalism relates to its value to its adherents first, and the African people generally, 'in an awakening Africa'.

Despite their seeming differences that contribute to lack of awareness of their oneness as African Christian community of the Spirit, all three sub-traditions regard the Bible as the authoritative Word of God.

They all approach it encounterologically because of the primacy they accord the role of the Holy Spirit, who not only inspired the writing of Scripture, but is active in its reading and re-enacting too. Also, their reading of the Bible comes with assumptions and perspectives attached to their socio-economic and cultural location. The pneumatic AICs are acknowledgedly churches of the poor, mostly urban marginalised and rural as well as culturally African traditional (Madise 2001:124). Mission Pentecostal churches are township based and also in the rural areas, with generally lower class people who have a tenuous relationship with African traditional culture (Clark 2001:95). Neo-Pentecostal churches are mostly filled with aspiring young, educated, professionals with a global outlook (Khanyile 2016:15-16; Omenyo 2014:137). These differing socio-economic and cultural experiences, as contexts of reading Scripture, tend to self-perpetuate, and although critical input promises renewal and growth, it often causes splits further fracturing the movement.
However, awareness of belonging to the same community, driven by those who so believe, may assist transcend divisions, and bring greater unity in quelling abuses.

\section{Towards a discerning and decolonising hermeneutic of experience}

The quest for a discerning and decolonising hermeneutic of experience is first about recognition of the centrality of this hermeneutic to APC. Secondly, it is about acknowledgement of existence of forces of capture that render this hermeneutic ineffective in environments where a cry for liberation exists and pointing to the need to overthrow such. Thirdly, it should be discerning because the forces of death may not have been all discovered, hence the necessity to remain vigilant. In the first instance, all the variant sub-traditions of APC are communities of the Spirit despite their different socioeconomic and cultural location. Besides their common expectation of a transformative encounter with the God of the Bible every time it is read, there are historical and theological links too (Lapoorta 1996:168). Hence, Lapoorta (1996:167-170) urges pursuit of relations among all three subtraditions. ${ }^{2}$ Judging each other on the basis of differing socioeconomic and cultural location is failure to discern the African Pentecostal body of Christ. It is weakening the power of the Spirit to hold this community together. In the second instance, the poverty that characterises the AICs and the opulence of the neo-Pentecostal ministries scandalises APC and cries out for resolution. The pursuit for bigger and better material blessings in neo-Pentecostalism seems to be egotistical and a distortion of God's concern and provision when seen from the perspective of the poor. The claims of exclusive relations with God by mission and neo-Pentecostal sub-traditions seem arrogant and anti-Christian to AICs for denying not only their status as Christians but the claimed presence of God at work in this sector (Anderson 2005:69). The marginalisation of women from leadership and ministry through appeal to patriarchal biblical and cultural scripts across the sub-traditions may be better dealt with when confronted with the historical fact of Spirit empowered women church founders and planters, prophets and healers (Dube 2014:2). In this broader community, the western evangelical hermeneutic which Mission Pentecostals employ towards Africanness may be challenged by the Afrocentric hermeneutical stance of the AICs. All these are a necessary critical input towards a discerning and decolonising hermeneutic of experience.

With the above said, the entire African Pentecostal community may learn from its constituent sub-traditions how to nurture a critical hermeneutic of experience by acknowledging its Africanness, its Christianness and the context in which it experiences the Spirit. Starting with acknowledging the

2.Lapoorta (1996) discusses the necessity of the AFM a classical Pentecostal denomination, pursuing relations with the Zionist Church movement and the neodenomination, pursuing relations with the Zionist Church movement and the neoPentecostal movement. In the context of this article, black Pentecostals of the above-mentioned denomination and others, are constituted into a sub-tradition of African Pentecostalism under which Zionists and neo-Pentecostals form two other sub-traditions. 
existence of its Africanness, the AICs' intentional preference for the Old Testament, which is acknowledgedly similar to the African religio-cultural world, is instructive (Mbiti 2004:222; Poewe 1988:150; Sundkler 1976:277) as it highlights the principle of being consciously African in relating to the Bible. Another principle emerging from how AICs interact with the Bible, and related to the above, is about the affirmation of Africans as God's children without mediation of foreign cultures (African Independent Churches 1985:21; Mbiti 2004:222). Maintenance of this consciousness questions the denigration of African culture in missionary Christianity (Mbiti 2004:222) and constitutes African lives as sites of struggle because of the violence Mofokeng (2018:94,99-103) outlines missionaries visited upon them, at least in the AFM.

The noted insistence that Mission and neo-Pentecostal disavow ancestors and the practices associated with the cultus, often taken to be a sign of evangelical commitment (Van Dijk 2000:8), Dube and Wafula (2017:9) interpret as a 'colonisation of the very soul of Africa' - therefore a perpetuation of individual and communal psycho-spiritual destruction from which it is difficult to emerge. To heal from effects of disconnected and divisive past, Lapoorta's (1996:154) challenge to have 'the courage to be black, African and Pentecostal' - albeit put in the context of the quest for unity of the formerly disparate racial section of the AFM applies.

Not only is it important to affirm the Africanness of the African Pentecostal community as a way of nurturing a critical hermeneutic of experience, the affirmation of this community's Christianness is important too. Despite the doubt initially cast by Sundkler (1961) about the Christianness of (some) AICs, reiterated by denominational Pentecostal leaders in Hollenweger (1972), including Bond (1974) and Larbi (2002:150), the number of scholars with positive evaluation of the contribution of AICs to Christianity is on the rise. This does not mean AICs need the affirmation of others as they consider themselves 'committed to biblical Christianity', which they find easy to do because of the closeness of African culture to the biblical one (African Independent Churches 1985:21). Within African Pentecostal community, Mission and neo-Pentecostals are yet to acknowledge the pioneering role of AICs in being African churches for Africans and their contextualising efforts. With neo-Pentecostals, this acknowledgement may not be difficult because neo-Pentecostal churches are themselves founded by Africans and exist structurally independent to any historic western denominations (Anderson 2002:170). According to Omenyo (2014:138), there are also signs of them increasingly embracing Old Testament-African cultural orientation in their leadership models and sacramental use of objects. The challenge for Mission Pentecostals is to divest themselves of attitudes denigrating AICs and Africanness, which Anderson (2005:69) claims were inherited from white Pentecostals. These attitudes stand in the way of discovering and affirming the Christianness of AICs and unlocking psycho-spiritual and cultural resources for reclamation of the Africanness of Mission Pentecostals. Acknowledging the essential oneness of the African Pentecostal community in its Christianness is a celebration of diversity that challenges this community to conversations about its varied experiences of itself and of other Christian communities.

Lastly, nurturing a critical African Pentecostal hermeneutic of experience requires acknowledgement of the context in which the Spirit is being experienced. This is a context of ascendant neo-liberalism, increasing economic disparity between the haves and the have-nots, corruption, abuse and religious duplicity.

Therefore, unmasking the contextual forces at play and the locus thereof as the human bodies of the African Pentecostal community is in keeping with the acknowledged materiality of both African and Pentecostal spiritualties (Clark 2001:81). The Spirit is experienced in the context of brokenness. Concern for the healing of the body has implications regarding the communal body constituted by individual bodies. The same applies to discernment of spirits that bring ubumnyama (a dark cloud of misfortune) to individuals. The link between the personal and the structural, and the potential of the latter to overwhelm the former, cannot be outside the ambit of the Spirit. Therefore, expanding the scope of discernment is critical. An example of discernment is how Dube (2014:2) decries the upholding of patriarchal hermeneutic that nullifies the work of the Spirit in liberating women to participate fully at all levels of leadership and ministry in the African Pentecostal community. She proposes a reclamation of the hermeneutic of the Spirit that enabled early Pentecostals, both African and western, to transcend race, gender, age and socio-economic barriers. The destructive practices associated with genderism, ageism, commodification of God's gifts and so on stand condemned under the hermeneutic of the Spirit that is alive to the historic and diverse experiences of the APC community.

\section{Conclusion}

In seeking to answer the question on what enables abuse in the hermeneutic of experience and how to remedy that situation, the researchers dislocated this question from its inspiration in the abuses emanating from some quarters of the neo-Pentecostal movement. They planted it within a broader framework of APC that includes pneumatic AICs, Mission Pentecostalism and neo-Pentecostalism. The argument for doing so is, firstly, that the acceptance of the Bible as the Word of God and the encounterological approach thereto is not a reserve of neo-Pentecostalism - APC as a whole subscribes to the same. Because the encountering of the Word is a contextual event, it becomes necessary to define the context of the encounter beyond the silos of what is arguably sub-traditions of a broader movement. Therefore, to the introduction of APC as a broader context in which the Word of God is encountered the researchers added the ascendant neo-liberal economic set-up in which corruption is rife, poverty runs rampant, people are desperate and religion is complicit in their misfortune. Secondly, in planting the question in the context of APC the researchers considered the 
resources of varied historical experiences of the constituent sectors of this broader movement and what looking at the question from this perspective exposes.

To conclude, the abuse extant in some quarters of APC is not necessarily characteristic of the hermeneutic of experience. Instead, it negates the founding narratives of the Pentecostal movement in which the victims of classism, racism, ethnicism, genderism, ageism and so on experienced the power of God and all these dehumanising restrictions ceased. From the beginnings of the Pentecostalism and still continuing, the erstwhile victims found their dignity in the Spirit's work among the lowly members of church and society.

The hermeneutic of experience is a hermeneutic founded on the work of the Holy Spirit and the Bible.

Factoring in the historic experiences of African Pentecostal believers as one community avails a critical and corrective hermeneutical resource to the reading of the Bible and discernment of the Spirit's contemporary activity. Those who perceive themselves better than others assume air of superiority over them, judge and exclude others who are heirs of the same blessing and are endowed with the same experiences of the Spirit, can be shown to violate this community of the Spirit. The remedy to the violence, which the community of the Spirit is exposed to, starts with recognition of this community's perculiarity of witness to the acts of God by which the lowly are raised and the haughty brought low. The story of Pentecostalism is of the God who constituted for himself a people from the rejects of civilised society. Therefore, the ability and willingness of the better off Pentecostals (within and across sub-traditions) to remember what God has done and may be continuing to do need to challenge them to be on the side of God and everybody else in this community - to be 'a brother's keeper'. An African Pentecostal hermeneutic of experience that ignores the varied experiences of racial and gender oppression, various abuses, joblessness, material want and the desperation for solutions that exposes people to harm and so on denies the power of God to transform and humanise life. This article suggests that the Bible be read in the context of a broader African Pentecostal community (in a locale), its experiences of the vicissitudes of life and God's ameliorating and saving activity within that community. Doing so introduces a critical hermeneutic of experience that may lessen abuse of Scripture and persons.

\section{Acknowledgement}

The authors acknowledge the Department of Christian Spirituality, Church History and Missiology for the support.

\section{Competing interest}

The authors declare that they have no financial or personal relationships which may have inappropriately influenced them in writing this article.

\section{Author contributions}

M.S.K. contributed in defining the hermeneutic of experience as a global concept and in an African context. M.S.K. also highlighted the role of hermeneutic of experience in the growth of African Pentecostal Christianity. T.R.M. contributed in outlining current challenges in African Pentecostal Christianity like relativism, exclusivism, lack of theory, judgemental views and the solution to such challenges.

\section{Ethical consideration}

This article followed all ethical standards for carrying out research without direct contact with human or animal subjects.

\section{Funding information}

Data sharing is not applicable to this article as no new data were created or analysed in this study.

\section{Data availability statement}

Data sharing is not applicable to this article as no new data were created or analysed in this study.

\section{Disclaimer}

The views and opinions expressed in this article are those of the authors and do not necessarily reflect the official policy or position of any affiliated agency of the authors.

\section{References}

African Independent Churches, 1985, Speaking for ourselves, Institute for Contextual Theology, Braamfontein.

Akoko, R., 2007, 'You must be born-again: The pentecostalisation of the Presbyterian Church in Cameroon', Journal of Contemporary African Studies 25(2), 299-315. https://doi.org/10.1080/02589000701396306

Anderson, A., 1996, 'Hermeneutical processes of Pentecostal-type African initiated Churches in South Africa', viewed 02 August 2018, from https://artsweb.bham. ac.uk/aanderson/Publications/hermeneutic.htm.

Anderson, A., 2001, African reformation: African initiated Christianity in the 20th century, Africa World Press, Trenton.

Anderson, A., 2002, 'The Newer Pentecostal and Charismatic Churches: The shape of future Christianity in Africa?', Pneuma 24(2), 167-184. https://doi. org/10.1163/15700740260388027

Anderson, A., 2005, 'New African Initiated Pentecostalism and charismatics in South Africa', Journal of Religion in Africa 35(1), 66-92. https://doi.org/10.1163/ 1570066052995843

Archer, K.J., 2004, 'Pentecostal story: The hermeneutical filter for the making of meaning', Pneuma 26(1), 36-59. https://doi.org/10.1163/157007404776111090

Becker, M., 2004, 'A tenet under examination: Reflections on the Pentecostal Hermeneutical approach', The Journal of the European Pentecostal Theological Association 24(1), 30-48. https://doi.org/10.1179/jep.2004.24.1.004

Bond, J., 1974, 'Pentecostalism in the Pentecostal churches', Journal of Theology for Southern Africa 1(1), 10-22.

Burger, I. \& Nel, M., 2008, The fire falls in Africa: A history of the apostolic faith mission of South Africa, Christian Art Publishers, Vereeniging.

Clark, M.S., 2001, 'The challenge of contextualization and syncretism to Pentecostal theology and missions in Africa', Journal of Asian Mission 3(1), 79-99.

CRL Rights Commission, 2017, 'Report on commercialization of religion and abuse of people's believe systems', viewed 03 September 2018, from https://www. crlcommission.org.za/docs/Report $\% 200$ n $\% 20$ Commecialization $\% 20$ of $\%$ OReligion $\% 20$ and $\% 20$ Abuse $\% 20$ of $\% 20$ People $\% 27$ s $\% 20$ Believe $\% 20$ Systems $\% 20$ final.pdf.

Dube, M., 2014, 'Between the spirit and the word: Reading the Gendered African Pentecostal Bible', HTS Teologiese Studies/Theological Studies 70(1), 1-7. https:// doi.org/10.4102/hts.v70i1.2651

Dube, M.W. \& Wafula, R.S., 2017, Postcoloniality, translation, and the Bible in Africa, Wipf and Stock Publishers, Eugene, OR.

Gabaitse, R.M., 2015, 'Pentecostal hermeneutics and marginalisation of women', Scriptura 114(1), 1-12. https://doi.org/10.7833/114-0-1043

Ganiel, G., 2010, 'Pentecostal and Charismatic Christianity in South Africa and Zimbabwe: A review', Religion Compass 4(3), 130-143. https://doi.org/10.1111/ j.1749-8171.2009.00203.x 
Gräbe, P., 2005, 'A perspective from Regent University's Ph.D. program in renewa studies: Theology in the light of the renewing work of the Holy Spirit', Pneuma 27(2), 124-129. https://doi.org/10.1163/157007405774270248

Gunda, M.R. \& Vengeyi, O., 2018, 'The primacy of the spirit: The case of African initiated Churches as Pentecostals', in L. Togarasei (ed.), Aspects of Pentecostal Christianity in Zimbabwe, pp. 49-62, Springer International Publishing, Cham. https://doi.org/10.1007/978-3-319-78565-34

Hollenweger, W.J., 1972, The Pentecostals, SCM Press, London.

Hwata, B., 2005, 'An investigation of different phases of Pentecostal experience in the Apostolic Faith Mission (AFM)', MTh Dissertation. UNISA.

Karkkainen, V.M., 1998, 'Pentecostal hermeneutics in the making: On the way from fundamentalism to postmodernism', Journal of the European Pentecostal Theological Association 18(1), 76-115. https://doi.org/10.1179/jep.1998.18.1.006

Kgatle, M.S., 2017, 'The unusual practices within some Neo-Pentecostal churches in South Africa: Reflections and recommendations', HTS Teologiese Studies/ Theological Studies 73(3), a4656. https://doi.org/10.4102/hts.v73i3.4656

Khanyile, S.B., 2016, 'The virtualization of the Church: New media representations of Neo-Pentecostal performance(s) in South Africa', MA Dissertation, University of Witwatersrand.

Khorommbi, N.L., 2001, 'Lutherans and Pentecostals in mission among the Vhavenda: A comparative study in missionary methods', Doctoral Thesis. UNISA.

Lapoorta, J.J., 1996, Unity or division? The unity struggle of the Black Churches within the Apostolic Faith Mission of South Africa, JJ Lapoorta, Kuils River, Cape Town.

Larbi, K., 2002, 'African Pentecostalism in the context of global pentecostal ecumenical fraternity: Challenges and opportunities', Pneuma 24(2), 138-166. https://doi. org/10.1163/15700740260388009

Madise, M.J.S., 2001, 'Christian healing in the African Independent Churches', Studia Historiae Ecclesiasticae 28(2), 122-132.

Masenya, M., 2005, 'The Bible and prophecy in African-South African Pentecostal Churches', Missionalia: Southern African Journal of Mission Studies 33(1), 35-45.

Mathole, E.M., 2005, 'The Christian witness in the context of poverty: With special reference to South African charismatic evangelicals', Doctoral Thesis, University of Pretoria.

Maxwell, D., 2006, African gifts of the spirit: Pentecostalism \& the rise of a Zimbabwean transnational religious movement, James Curry, Oxford.

Mbiti, J.S., 2004, 'The role of the Jewish Bible in African independent Churches' International Review of Mission 93(369), 219-237. https://doi.org/10.1111/ j.1758-6631.2004.tb00455.x

Mofokeng, T., 2018, 'Throwing the baby out with the bathwater: Cultural reorientation of black Pentecostalism in the apostolic faith mission of South Africa (1940-1975)', MTh Dissertation. UNISA.

Mofokeng, T. \& Madise, M., 2019, 'The evangelicalisation of Black Pentecostalism in the AFM of SA (1940-1975): A turning point', Studia Historiae Ecclesiasticae 45(1), 16. https://doi.org/10.25159/2412-4265/4050
Mojola, A., (in press), 'The old testament or Hebrew Bible in Africa: Challenges and prospects for interpretation and translation', Verbum et Ecclesia 35(3), 7. https:// doi.org/10.4102/ve.v35i3.1307

Moore, R.D., 1987, 'A Pentecostal approach to scripture', Seminary Viewpoint 8(1), $4-11$.

Nel, M., 2015, 'Attempting to define a Pentecostal hermeneutics', Scriptura 114(1), 1-21. https://doi.org/10.7833/114-0-1044

Nel, M., 2017, 'Pentecostal hermeneutical considerations about women in ministry', Studia Historiae Ecclesiasticae 43(1), 122-137. https://doi.org/10.25159/2412 $4265 / 2126$

Nel, M. \& Janse van Rensburg, F., 2016, 'Integrating spirituality and rationality the long and arduous journey of the historical development of theological training in the apostolic faith mission of South Africa', In die Skriflig 50(2), 1-10. https://doi. org/10.4102/ids.v50i2.1943

Omenyo, C.N., 2014, 'African Pentecostalism', in C.M. Robeck Jr. \& A. Yong (eds.), The Cambridge companion to Pentecostalism, pp. 132-151, Cambridge University Press, New York, NY.

Phiri, J.K., 2009, 'African Pentecostal Spirituality: A study of the emerging African Pentecostal Churches in Zambia', Doctoral thesis, University of Pretoria.

Plüss, J.D., 2003, 'Religious experience in worship: A Pentecostal perspective', PentecoStudies 2(1), 1-21.

Poewe, K., 1988, 'Links and parallels between black and white charismatic Churches in South Africa and the states: Potential for cultural transformation. Pneuma', The Journal of the Society for Pentecostal Studies 10(2), 141-158. https://doi. org/10.1163/157007488X00091

Resane, K.T., 2016, 'And they shall make you eat grass like oxen (Daniel 4:24): Reflections on recent practices in some New Charismatic Churches', Pharos Journal of Theology 98(1), 1-17.

Resane, K.T., 2017, 'Miracles in the neo-Charismatic movement: Historical and theological critique', Verbum et Ecclesia 38(1), 1-8. https://doi.org/10.4102/ve. v38i1.1736

Sundkler, B., 1961, Bantu Prophets in South Africa, 2nd edn., Oxford University Press, London.

Sundkler, B., 1976, Zulu Zion and some Swazi Zionists, Oxford University Press, London.

Van Dijk, R., 2000, 'Christian fundamentalism in sub-Saharan Africa: The case of Pentecostalism', Leiden, the Netherlands: Africa Studies Centre, viewed 09 August 2017, from https://www.ascleiden.nl/publications/christian-fundamentalismsub-saharan-africa-case-pentecostalism.

Wenk, M., 2003, 'Do we need a distinct European Pentecostal/Charismatic approach to theological education?', The Journal of the European Pentecostal Theological Association 33(1), 58-71. https://doi.org/10.1179/jep.2003.23.1.005

Yong, A., 2007, 'Pentecostals and the theological academy', Theology Today 64(2), 244-250. https://doi.org/10.1177/004057360706400209 